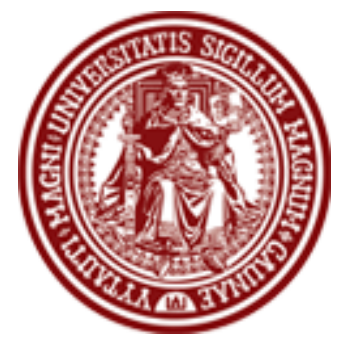

BALTIC JOURNAL OF LAW \& POLITICS

VOLUME 2, NUMBER 1 (2009)

ISSN 2029-0405

http://www.versita.com/science/law/bjlp

Cit.: Baltic Journal of Law \& Politics 2:1 (2009): 83-96

DOI: $10.2478 / v 10076-009-0005-9$

\title{
THE SUBJECTS OF PUBLIC INTERNATIONAL LAW IN A GLOBALIZED WORLD
}

\author{
Stefan Kirchner \\ Research Assistant \\ Georg August University, Faculty of Law (Germany) \\ Doctoral Student \\ Justus Liebig University, Faculty of Law (Germany)
}

Attorney at Law (Rechtsanwalt, admitted to the bar in Germany) Rechtsanwaltskanzlei Kirchner, Antrifttal (Germany)

\section{Contact information}

Address: Georg-August-University, Chair for Public Law, in particular Religious Law and the Constitutional Law of Religious Communities, Gosslerstrasse 11, 37073 Göttingen, Germany; Justus-Liebig-University, Chair for International, Public and European Law, Licher Strasse 76, 35390 Giessen, Germany; Rechtsanwaltskanzlei Kirchner, Alsfelder Straße 27, 36326 Antrifttal, Germany.

Phone: +49 6631 80282-9.

E-mail address: kanzlei@stefankirchner.org, kirchnerlaw@yahoo.com.

Received: June 15, 2009; reviews: 2; accepted: July 20, 2009.

\begin{abstract}
Today we are witnessing a fundamental shift in Public International Law (PIL) in which the number of actors increases dramatically and in which communication means power. The matrix of PIL is undergoing a major change. This change is not abrupt but has to be seen in the context of the shift away from the Westphalian model of PIL since 1945. Also, globalization is not a new phenomenon, although the current era of globalization, which was made possible due to the fall of the iron curtain and recent technological developments, raises the question how to describe the emerging international legal community in terms of international legal theory. As the importance of the role of the state as an actor of international law is reduced (albeit not to a degree that the state would lose its de facto primacy among the subjects of international law), other actors are gaining ground, in particular international organizations, transnational corporations, NGOs and individuals.
\end{abstract}


Today the latter not only have rights under Public International Law but are also involved in the creation of new rules of international law.

\section{KEYWORDS}

Globalization, transnational corporations, non-state actors, public international law, legal history, NGOs, human rights

\section{NOTE AND ACKNOWLEDGEMENT}

This text is based on a presentation given at Vytautas Magnus University in Kaunas in May 2009 and only reflects the private opinion of the author, who also wishes to thank the dean of the Faculty of Law of Vytautas Magnus University, doc. dr. Julija Kiršiene, as well as dr. Tomas Berkmanas, doc. dr. Edita Gruodyte and Mindaugas Bilius. 


\section{INTRODUCTION}

Globalization is not a new phenomenon but today the internet is one of the most visible facets of globalization. In his bestselling book "The World is Flat", Thomas L. Friedman offers a good description of the development of globalization, although one which is somewhat U.S.-centric and obviously inspired by modern technology. The starting point for Friedman is the so-called discovery of the Americas by Christopher Columbus in $1492 .{ }^{1}$ The following centuries Friedman refers to as "Globalization 1.0 ", covering the timeframe until the year $1800 .^{2}$ The era between Industrialization and Internet, roughly from the year 1800 to the year 2000 he refers to as "Globalization 2.0". ${ }^{3}$ In this phase, he sees multinational firms and transnational companies (TNCs) ${ }^{4}$ to have a dominant role, ${ }^{5}$ supported by the expansion of infrastructure such as road, railway and sea traffic as well as by sinking costs of long-distance communication. ${ }^{6}$ It was the new role of telecommunication and in particular the increased access to means of telecommunication which started the next level of globalization. At the same time the current era of globalization has contributed significantly to the creation of a global "level playing field". Although a large part of the world's population still lives in unacceptable poverty, millions now have, for the first time, the chance to participate in the global marketplace. This marketplace also is no longer merely economic but is becoming all-inclusive, involving basic education as well as scientific research. Many examples easily come to mind, from access to news from the most remote corners of the earth at your fingertips, to mobile-phone-banking in Africa, from affordable distance education to affordable loans. Any list of examples I give here will probably already be outdated by the time this text goes to print. Mobile phones, Internet and Email are only some technical aspects, but they empower many, in particular since everybody can create and access content online. ${ }^{7}$ The current wave of globalization has a dramatic impact on billions of people around the world. This development has led Friedman to conclude that the world has, in his words, become "flat". This was not a planned development, it just happened. ${ }^{8}$ It happened because we are making use of the opportunities we have. At this point in history, globalization is no longer the exclusive realm of states or

\footnotetext{
1 Thomas L. Friedman, The World is Flat - The Globalized World in the Twenty-First Century, $2^{\text {nd }}$ ed., (London: Penguin Books Ltd., 2006), p. 9.

${ }^{2}$ Ibid.

3 Ibid.

${ }^{4}$ As we will see later, TNCs played an important role far earlier than Friedman describes.

5 Ibid.

${ }^{6}$ Ibid.

7 Ibid., p. 10.

${ }^{8}$ Ibid., p. 11.
} 
transnational corporations. At some point, this globalization fell into the hands of ordinary people and they, we, are driving globalization now. This could be called "globalization 3.0", to use Friedman's terminology. ${ }^{9}$ I disagree somewhat with Friedman in that I see five major eras of globalization rather than three, but agree with him in principle. For the purposes of this paper, I suggest that the five eras of globalization were or are $1^{\text {st }}$ an Iberian Phase from 1492 until around the French Revolution, $2^{\text {nd }}$ an Imperial Phase between the French Revolution and World War I, a time in which the great powers attempted to become empires rather than mere states, $3^{\text {rd }}$ World War II as a form of globalization based on military rather than economic cooperation, $4^{\text {th }}$ the time between 1945 and 1989 which saw increased economic cooperation between states at a time when the world as a whole was separated in two major blocks, and our current age of globalization which was made possible due to the fall of the iron curtain two decades ago and the technological developments of the last years. ${ }^{10}$ While this might be a question for future historians, as lawyers we are facing important questions today, in particular in the field of international economic law, ${ }^{11}$ which is particularly affected by globalization, but also for Public International Law (PIL) as a whole. The question which remains open as globalization progresses is how to describe the emergent international community which is born from the current era of globalization in terms of legal theory and philosophy?

\section{GENERAL OVERVIEW}

Law always is a mirror of the conditions and cultural traditions of the society to which it applies. ${ }^{12}$ Changes in the membership in this society or community can be spontaneous and affect the law as a whole. ${ }^{13}$ Since the end of the Cold War, the "importance of actor perception"14 has increased, which leads to the question as to who is the subject of this globalizing legal order. After all, the range of issues covered by Public International Law is immense, ranging literally from the exploitation of resources at the bottom of the ocean to the use of Outer Space and covering virtually all interests of contemporary international life. ${ }^{15}$ An entity is a

\footnotetext{
${ }^{9}$ Ibid.

10 Stefan Hobe and Otto Kimminich, Einführung in das Völkerrecht [Introduction to Public International Law], $8^{\text {th }}$ ed. (Tübingen: A. Francke Verlag, 2004), p. 61.

${ }^{11}$ Ibid.

12 Malcom Shaw, International Law, $4^{\text {th }}$ ed. (Cambridge: Cambridge University Press, 1997), p. 36.

${ }^{13}$ Ibid.

${ }^{14}$ Richard A. Falk, Legal Order in a Violent World, $1^{\text {st }}$ ed. (Princeton: Princeton University Press, 1968), p. 82 .

${ }_{15}$ Malcom Shaw, supra note 12 , pp. 36 et seq.
} 
legal subject of Public International Law, if it is legally able to hold rights and obligations and to claim such rights on an international stage. ${ }^{16}$

But although all states are equal, ${ }^{17}$ not all subjects of international law are equal. ${ }^{18}$ Not only do different subjects of international have law different rights and obligations, they enjoy subjectivity to different degrees. ${ }^{19}$ Traditionally international law scholars differentiate between partial and particular subjects of international law. Partial subjects are those subjects who, to the extent and limitations of their capability, are depending on themselves when they enter into legal relations under international law. A typical example are international intergovernmental organizations which only enjoy the capability to enter into legal relations as far as their respective constitutive documents, usually international treaties between states, allow. ${ }^{20}$ Particular subjects of international law on the other hand are such subjects of international law which only enjoy the capability to enter into legal relations with regard to certain other subjects of international law. ${ }^{21}$

PARTIAL AND PARTICULAR SUBJECTS OF PUBLIC INTERNATIONAL LAW

Table 1

\begin{tabular}{|c|c|c|}
\hline \multirow{2}{*}{$\begin{array}{c}\text { Capacity to enter into legal } \\
\text { relations with other subjects } \\
\text { of international law }\end{array}$} & \multicolumn{2}{|c|}{ Full capacity } \\
\cline { 2 - 3 } & Partial & \multicolumn{2}{|c|}{ Particular } \\
\cline { 2 - 3 } & $\begin{array}{c}\text { Limitation with regard to } \\
\text { potential issues }\end{array}$ & $\begin{array}{c}\text { Limitation with regard } \\
\text { to potential partners }\end{array}$ \\
\hline
\end{tabular}

For example recognition by other states is not a requirement for statehood, but as John Dugard has explained in the case of the Bantustan states, ${ }^{22}$ collective non-recognition is a serious impediment to the capability of a legal entity to enter into legal relations with others.

${ }^{16}$ Ian Brownlie, Principles of Public International Law, $5^{\text {th }}$ ed. (Oxford: Oxford University Press, 1998), p. 57.

17 The general principle of sovereign equality of states is codified in Art. 2, No. 1 of the Charter of the United Nations.

${ }_{18}$ Malcom Shaw, supra note 12, pp. 137 et seq.

${ }^{19}$ Cf. ibid., p. 138

${ }^{20}$ See Stefan Hobe and Otto Kimminich, supra note 10, p. 66.

${ }^{21}$ Ibid.

22 John Dugard, International Law - A South African Perspective, $2^{\text {nd }}$ ed. (Lansdowne: Juta Law, 2001), pp. 445 et seq. 
I am of the opinion that this concept applies to all potential subjects of international law: they get their factual power from the ability to play a role. In other words, they act because they dare to raise their voice and because they are heard. This view has its roots in an analogy to Article 1 lit. d) of the Montevideo Convention on the Rights and Duties of States. Although a treaty between American states, the Montevideo Convention can be considered to codify the customary law concerning the prerequisites for statehood, namely a) territory, b) population, c) government and the d) capability to enter into relations with other states. As the system of PIL includes ever more non-state actors, the latter requirement, the capability to enter into legal relations with other actors of PIL, which emerged in a state-centered system of PIL, should now be applied to all potential subjects of PIL. The capability to enter into relations with others is now becoming the key test for the determination whether or not an entity is indeed a subject of PIL.

I therefore suggest a fundamentally new type of differentiation: between those subjects which have rights and obligations under international law (subject to the law) and those subjects which are involved in the creation of new law (law makers, subject in the active sense, like the subject in the linguistic or grammatical sense is the active part of a sentence). This does not mean that the existing differentiations become obsolete, but that we add an additional dimension to it the differentiation between mere subjects to the law and those subjects which have a chance to actually change the law.

ADDING A NEW DIMENSION TO THE MATRIX

(EXAMPLES ARE NOT MEANT TO BE EXHAUSTIVE)

Table 2

\begin{tabular}{|l|c|c|}
\hline \multirow{2}{*}{ Full subjects } & e.g.: states & $\begin{array}{c}\text { e.g.: universally recognized } \\
\text { states }\end{array}$ \\
\hline Partial subjects & e.g.: individuals & $\begin{array}{c}\text { e.g.: international } \\
\text { organizations }\end{array}$ \\
\hline \multirow{2}{*}{ Particular subjects } & e.g.: states recognized only by some subjects of international law \\
\hline & \multicolumn{2}{|c|}{ subject to the law law makers } \\
\cline { 2 - 3 } & \multicolumn{2}{|c|}{ actors } \\
\cline { 2 - 3 } & &
\end{tabular}




\section{THE STATE}

Since the Peace of Westphalia, which ended the Thirty-Years-War in 1648, the State has been the key player in international law. Even in an era of massive globalization like we are experiencing today, the needs and characteristics of the existing international political system remain the raison d'être and determining factor of Public International $\mathrm{Law}^{23}$ and in this political system the state continues to play the leading role. But it no longer has the stage all for itself. States are more and more integrated in communities, such as the European Union, which leads to a transfer of sovereignty. But for many of us, the national state is simply "the" form of human organization on a large scale, despite the fact that many of you will vote in a few days for a far-away parliament which transcends borders which were impenetrable just two decades ago.

But if we look elsewhere, we can see that other large scale legal communities exist, such as the Pashtuns in the Afghanistan-Pakistan border area who live under the Pashtunwali, a law which applies to all Pashtuns, making the artificial border between Afghanistan and Pakistan irrelevant. As a matter of fact, we do not have to look that far back into history to realize that many Lithuanians, for example, and also myself, are part of a large community which transcends borders and has done so for almost 2,000 years. The Catholic Church is also a legal community and its Code of Canon Law applies to all Roman Catholics, ${ }^{24}$ regardless of their nationality or location. And finally the European Union is growing ever closer together - so close that the question can be asked if Europe has already achieved such a degree of closeness as to have lead to the creation of a European body politic. ${ }^{25}$ These are just some examples which challenge us to think outside the narrow confines of the national state.

\section{CLASSICAL NON-STATE ACTORS IN PUBLIC INTERNATIONAL LAW ${ }^{26}$}

In point of fact, the state has never been completely alone on the international stage, although it dominated it for a long time. In the pre-Westphalian era, what we would now call "international" treaties were often treaties between

\footnotetext{
23 Malcom Shaw, supra note 12 , p. 37.

${ }^{24}$ Code of Canon Law: can. 1 ; can $12 \S 1$.

25 Cf. Roman Herzog, "Verfassungsfragen der Zukunft [Constitutional Questions of the Future]," in: Jutta Limbach, Roman Herzog, and Dieter Grimm, Die deutschen Verfassungen: Reproduktionen der Verfassungsoriginale von 1849, 1871, 1919 sowie des Grundgesetzes von 1949 [The German Constitutions: Reproductions of the Original Constitutions of 1849, 1871, 1919 as well as of the Basic Law of 1949], $1^{\text {st }}$ ed. (Munich: C. H. Beck, 1999), pp. 30 et seq., at p. 39; Heinz Kleger, Ireneusz Pawel Karolewski, and Matthias Munkel, Europäische Verfassung: Zum Stand der europäischen Demokratie im Zuge der Osterweiterung [European Constitution: on the Current Status of European Democracy in the Context of the Eastern Enlargement], $3^{\text {rd }}$ ed. (Münster: Lit Verlag, 2004), p. 102.

${ }^{26}$ On non-state actors and their role in international law see Andrea Bianchi, ed., Non-State Actors and International Law, $1^{\text {st }}$ ed. (Farnham: Ashgate Publishing, 2009).
} 
sovereigns, like the treaty between Hattusilis III, king of the Hittites, and Ramses II from the year 1269 B.C., ${ }^{27}$ a replica of which today is on display at UN Headquarters in New York. ${ }^{28}$ But already the oldest known international treaty, between the leaders of the Mesopotamian city states Lagash and Umma, dating back to the year 3100 B.C. ${ }^{29}$ linked the signatories to their respective functions in their communities. A remnant of this age is found today in the person of the Pope: the Holy $\mathrm{See}^{30}$ (not to be confused with the state of the Vatican City ${ }^{31}$ ), who is one of the oldest non-state actors in Public International Law. Often it is the Holy See which is party to international treaties. In contrast, the state of the Vatican City is an international legal subject of its own, on par, due to the principle of the sovereign equality of states, with all other states, despite its small geographical size. Unlike the Holy See, the state of the Vatican, as we know it today, only came into existence a mere 80 years ago with the Lateran Treaties between the Holy See and the Italian Republic, which date back to 11 February 1929 and which were concluded to resolve the so-called "Roman Question" which arose after the Papal States had been conquered by Italian forces on 11 September 1870 . Until that day the pope had had his own state since at least the Sutri donation in the year $728 .{ }^{32}$ Only in May 1871 Italy accepted the sovereignty of the pope over the Lateran. The Vatican gained statehood only in 1929 and, in fact, Italian laws directly applied in the Vatican City (unless in violation of church laws) until the end of 2008. During all this time, the international legal status of the Holy See was not affected.

A number of other non-state actors have been subjects of international law for some time, at least partially. Among them the Sovereign Military Hospitaller Order of St. John of Jerusalem of Rhodes and of Malta (also known as the Sovereign Order of Malta), ${ }^{33}$ insurgents, ${ }^{34}$ war-farring groups, ${ }^{35}$ national liberation movements, $^{36}$ international Organisations, ${ }^{37}$ international public companies, ${ }^{38}$ transnational corporations (TNCs) ${ }^{39}$ and individuals. ${ }^{40}$

\footnotetext{
27 Edmund Jan Osmańczyk and Anthony Mango, Encyclopedia of the United Nations and International Agreements, Volume 2: G-M, $3^{\text {rd }}$ ed. (London: Taylor \& Francis, 2003), p. 1115.

28 Ibid.

29 Ibid.

30 Malcom Shaw, supra note 12, p. 172.

${ }^{31}$ Cf. ibid.

32 The Sutri Donation was in fact also an "international" treaty between two sovereigns, Luitprand, king of the Lombards, and Pope Gregory II.

33 Malcom Shaw, supra note 12 , p. 171.

34 Ibid., p. 173.

35 Ibid.

${ }^{36}$ Cf. Antonio Cassese, International Law, $1^{\text {st }}$ ed. (Oxford: Oxford University Press, 2001), pp. 75 et seq.; Malcom Shaw, supra note 12, pp. 173 et seq.

37 Antonio Cassese, supra note 36, pp. 70 et seq.

38 Malcom Shaw, supra note 12 , pp. 175 et seq.

39 Ibid., pp. 176 et seq.

${ }^{40}$ Antonio Cassese, supra note 36, pp. 77 et seq.
} 
The latter two groups are of particular interest in the context of globalization. I want to show you that both transnational corporations and individuals have had some role on the international stage for much longer than many seem to assume today.

\section{TRANSNATIONAL CORPORATIONS ${ }^{41}$}

Transnational corporations are often seen as the driving force behind the current era of globalization. Although they do not play an exclusive role, their impact certainly is undeniable. So far, Public International Law fails to take the role of TNCs into account in an adequate manner. TNCs should at least be covered by codes of conduct like those which have been created by the ILO or the OECD ${ }^{42}$ and which are intended to require TNCs to respect the sovereignty of their respective host states, ${ }^{43}$ in particular in the developing world. Until today, however, the necessary consensus between industrialized and developing countries regarding such obligations remains missing. Consequently most rules in this field only amount to soft law. ${ }^{44}$

All of this seems to imply that transnational corporations are a new phenomenon and that international law is not yet fully equipped to deal with this issue, although there is some progress, in particular in the field of international economic law. Today, international economic law is taking into account the interests of private businesses and giving corporations the opportunity to participate in international disputes. Since the decision of the World Trade Organization (WTO) Appellate Body in the Shrimp Turtle case, ${ }^{45}$ corporations can participate in dispute settlement proceedings under Art. 13 of the WTO Dispute Settlement Understanding and Annex VI Art. 20 Sec. 2 of the International Convention on the Law of the Sea (LOSC) envisages a legal status for corporations involved in deep sea mining. ${ }^{46}$ For the time being, though, TNCs neither have the status nor the obligations under international law which would be adequate given their factual economic power.

\footnotetext{
${ }^{41}$ Cf. Fleur Johns, "The Invisibility of the Transnational Corporation: an Analysis of International Law and Legal Theory," Melbourne University Law Review 19 (1993-1994): 893 et seq.; Larry Catá Backer, "Multinational Corporations, Transnational Law: The United Nations' Norms on the Responsibilities of Transnational Corporations as a Harbinger of Corporate Social Responsibility in International Law," Columbia Human Rights Law Review 2005: 101 et seq.

${ }^{42}$ Stefan Hobe and Otto Kimminich, supra note 10, p. 157.

${ }^{43}$ Ibid.

${ }^{44}$ See e.g. Norms on the Responsibilities of Transnational Corporations and Other Business Enterprises with Regard to Human Rights, U.N. Doc. E/CN.4/Sub.2/2003/12/Rev.2 (2003).

${ }^{45}$ Cf. Debra Johnson and Colin Turner, International Business, $1^{\text {st }}$ ed. (London: Routledge, 2003), p. 301.

${ }^{46}$ Stefan Hobe and Otto Kimminich, supra note 10, p. 158.
} 
Interestingly enough, this is actually a large step backwards. Transnational corporations are not as new a phenomenon as one might think. As early as the year 1600 the English East India Company (E.I.C.) and, more importantly, two years later, the Dutch United East India Company (V.O.C.) were the first multinational corporations. The more successful V.O.C. ${ }^{47}$ operated from 1602 until 1798. It was the first company based on shares. Its business was based on a monopoly for trade between the Netherlands and the entire area east of the Cape of Good Hope and West of the Magellan Strait, including the Indian and Pacific Oceans. It was a company under Dutch law, not owned by the Dutch state (although it was generally understood that the V.O.C. represented Dutch interests in the region). It was run by traders who in turn represented local trade groups from different Dutch cities, the Heren XVII. But the V.O.C. differed fundamentally from modern TNCs in that it not only established bases abroad, the V.O.C. even waged war against Portugal and conquered Malakka in 1641 and supported the Sultans of Banten in Western Java in their wars in return for more monopolies. In a footnote of the history of the V.O.C., a trading post was established at the Cape of Good Hope in 1652, eventually leading to the establishment of what we now know as the Republic of South Africa. There we have a TNC which makes war and establishes trading posts. Although there was some domestic Dutch control over the V.O.C., the latter acted at least as a proxy for the Netherlands and in many respects acted in their own right. Thereby the V.O.C. at least had a role in both international affairs and international law. This cannot be said to the same extent of today's TNCs. Yet their impact on the lives of many is not much less, if we think of the poor working conditions in sweat shops in Asia or maquiladoras in Latin America, or if we think of child labour and unpaid wages. Today's TNCs can enjoy many freedoms due to their economic power but they also enjoy the sheltering walls of their home states if they feel compelled to do so, thus often avoiding responsibility for their actions abroad.

\section{INDIVIDUALS}

Just like TNCs, individuals are being mediated in classical PIL. ${ }^{48}$ Although Westphalian PIL includes rules concerning the conduct of states vis-à-vis individuals, the latter were at best beneficiaries of the rights of their home state against an other rather than holders of rights in their own right and they required diplomatic protection of their interests by their home state ${ }^{49}$ because they were

\footnotetext{
47 On the role of the V.O.C. cf. Jonathan I. Israel, The Dutch Republic - Its Rise, Greatness, and Fall 1477-1806, $1^{\text {st }}$ ed. (Oxford: Clarendon Press, 1998), pp. 934 et seq.

48 Stefan Hobe and Otto Kimminich, supra note 10, pp. 153 et seq.

49 On the fundamental nature of diplomatic protection in international relations cf. Ian Brownlie, supra note 16, pp. 391 et seq. as well as the references given there; Wilhelm Karl Geck, "Diplomatic
} 
unable to claim these rights themselves. ${ }^{50}$ In other words, diplomatic protection meant that the interests of the state are inseparable from those of the citizen. ${ }^{51}$

With the emergence of international human rights law after World War II, individuals have been given the opportunity to sue states, including their own, for violations of their own rights under international law, for example at the European Court of Human Rights in Strasbourg. But if this opportunity does not exist (and, despite emerging changes in the African Human Rights system, this opportunity still does not exist for the vast majority of people, in particular in Asia), diplomatic protection is still relevant today. ${ }^{52}$

The position of the individual (as well as the position of other non-state actors) in the matrix of PIL is shifting. Until the advent of international human rights law, individuals did not register within this matrix at all; they were at best mere beneficiaries. Today they are partial subjects of international law. But modern technology, in particular in the field of telecommunication, enables individuals to take a greater role in the creation of new rules of Public International Law, albeit often through the mediation of other actors. Unlike in the past, the state is no longer the only mediator but other actors, for example NGOs or TNCs, take an ever increasing role in this context. Two recent examples involve the Ottawa Convention which led to the Ban of Land Mines and the Rome Statute establishing the International Criminal Court, both of which profited greatly from the involvement of individuals and NGOs.

\section{CONCLUSIONS}

In a world in which actors, as we have seen, derive their influence from communication with other actors, this increased role of non-state actors is the logical consequence of the movement away from the state-centered, Westphalian, system of PIL. Modern technology and economic globalization only hasten this process and we are reminded that the state, the dominant actor in international law

Protection," in: Rudolf Bernhardt, ed., Encyclopedia of Public International Law, Volume I: Aalands Islands to Dumbarton Oaks Conference (1944), $1^{\text {st }}$ ed. (Amsterdam: North-Holland, 1992), pp. 1045 et seq., at p. 1046. On the relatively small practical importance of international litigation for diplomatic protection cf. Keith Hamilton and Richard Langhorne, The Practice of Diplomacy - its evolution, theory and administration, $1^{\text {st }}$ ed. (London, New York: Routledge, 1995), p. 238. Also see Peter R. Baehr, The Role of Human Rights in Foreign Policy, $2^{\text {nd }}$ ed. (Houndsmills: Macmillan Press, 1996), pp. 31 et seq., who does not mention diplomatic protection among potential policy instruments for human rights protection; cf. Andrew Hurrell, "Power, Principles and Prudence: Protecting Human Rights in a Deeply Divided World," in: Tim Dunne and Nicholas J. Wheeler, eds., Human Rights in Global Politics, $1^{\text {st }}$ ed., (Cambridge: Cambridge University Press, 1999), pp. 277 et seq., who also concentrates on human rights of local citizens abroad rather than rights of aliens abroad.

${ }^{50}$ German Federal Supreme Court, BGHZ Vol. 155: 279 et seq., 291 et seq.

${ }^{51}$ United States v. Italy - Elettronica Sicula S.p.A. (ELSI), International Court of Justice, Judgment of 20

July 1989 (IC] Reports 1989): 15 et seq., 42 et seq.

52 German Federal Supreme Court, supra note 50. 
for the last 350 years, is only a collection of people, a human creation, ${ }^{53}$ a fiction, a necessary abstraction. In the past, we have decided to organize ourselves in states - big tribes, essentially. In a sense, the emergent international legal community is similar to the one described by Francisco de Vitoria around 500 years ago, ${ }^{54}$ who saw a community which includes both states and individuals. Modern, communication-based PIL, actually goes a step further as to include groups of people which are organised in non-state organisations, for example NGOs or TNCs. This new PIL still observes the sovereign equality of states but gives a place for new actors, without putting them on an equal level with existing actors. But the latter is not absolutely necessary, since all actors gain their power from the ability to communicate. Therefore the right to be heard will become an ever more important aspect of PIL. In a world which is driven by communication, it is up to all actors to safeguard this elementary prerequisite of the new PIL.

\section{BIBLIOGRAPHY}

1. Baehr, Peter R. The Role of Human Rights in Foreign Policy. $2^{\text {nd }}$ ed. Houndsmills: Macmillan Press, 1996.

2. Bianchi, Andrea, ed. Non-State Actors and International Law. $1^{\text {st }}$ ed. Farnham: Ashgate Publishing, 2009.

3. Brownlie, Ian. Principles of Public International Law. $5^{\text {th }}$ ed. Oxford: Oxford University Press, 1998.

4. Cassese, Antonio. International Law. $1^{\text {st }}$ ed. Oxford: Oxford University Press, 2001.

5. Backer, Larry Catá. "Multinational Corporations, Transnational Law: The United Nations' Norms on the Responsibilities of Transnational Corporations as a Harbinger of Corporate Social Responsibility in International Law." Columbia Human Rights Law Review (2005): 101 et seq.

6. Dugard, John. International Law - A South African Perspective. $2^{\text {nd }}$ ed. Lansdowne: Juta Law, 2001.

7. Falk, Richard A. Legal Order in a Violent World. $1^{\text {st }}$ ed. Princeton: Princeton University Press, 1968.

\footnotetext{
53 José Llompart, "Proklamation der Volkssouveränität in den modernen Verfassungen [Proclamation of People's Sovereignty in the Modern Constitutions]," in: Werner Krawietz, Ernesto Garzón Valdés, and Agustín Squella, eds., Politische Herrschaftsstrukturen und Neuer Konstitutionalismus - Iberoamerika und Europa in theorievergleichender Perspektive, Rechtstheorie, Beiheft 13 [Political Structures of Governance and New Constitutionalism - Iberoamerica and Europe in Theory-Comparing Perspective, Legal Theory, Supplement 13], $1^{\text {st }}$ ed. (Berlin: Duncker \& Humblot, 2000), pp. 143 et seq.

54 Francisco de Vitoria, "De indis," in: Ulrich Horst, Heinz-Gerhard Justenhoven, and Jocahim Stüben, Francisco de Vitoria - Vorlesungen II (Relectiones) - Völkerrecht - Politik - Kirche [Francisco de Vitoria - Lectures II (Relectiones) - Public International Law - Politics - Church], $1^{\text {st }}$ ed. (Stuttgart: Verlag W. Kohlhammer, 1997), pp. 370 et seq.
} 
8. Friedman, Thomas L. The World is Flat - the Globalized World in the TwentyFirst Century. $2^{\text {nd }}$ ed. London: Penguin Books Ltd., 2006.

9. Geck, Wilhelm Karl. "Diplomatic Protection." In: Rudolf Bernhardt, ed. Encyclopedia of Public International Law. Volume I: Aalands Islands to Dumbarton Oaks Conference (1944). $1^{\text {st }}$ ed. Amsterdam: North-Holland, 1992: 1045 et seq.

10. Hamilton, Keith, and Richard Langhorne. The Practice of Diplomacy - its Evolution, Theory and Administration. $1^{\text {st }}$ ed. London, New York: Routledge, 1995.

11. Herzog, Roman. "Verfassungsfragen der Zukunft [Constitutional Questions of the Future]." In: Jutta Limbach, Roman Herzog, and Dieter Grimm. Die deutschen Verfassungen: Reproduktionen der Verfassungsoriginale von 1849, 1871, 1919 sowie des Grundgesetzes von 1949 [The German Constitutions: Reproductions of the Original Constitutions of 1849,1871, 1919 as well as of the Basic Law of 1949]. $1^{\text {st }}$ ed. Munich: C. H. Beck, 1999: 30 et seq.

12. Hobe, Stefan, and Otto Kimminich. Einführung in das Völkerrecht [Introduction to Public International Law]. $8^{\text {th }}$ ed. Tübingen: A. Francke Verlag, 2004

13. Hurrell, Andrew. "Power, Principles and Prudence: Protecting Human Rights in a Deeply Divided World." In: Tim Dunne and Nicholas J. Wheeler, eds. Human Rights in Global Politics. $1^{\text {st }}$ ed. Cambridge: Cambridge University Press, 1999: 277 et seq.

14. Israel, Jonathan I. The Dutch Republic - Its Rise, Greatness, and Fall 14771806. $1^{\text {st }}$ ed. Oxford: Clarendon Press, 1998.

15. Johns, Fleur. "The Invisibility of the Transnational Corporation: an Analysis of International Law and Legal Theory." Melbourne University Law Review 19 (1993-1994): 893 et seq.

16. Johnson, Debra, and Colin Turner. International Business. $1^{\text {st }}$ ed. London: Routledge, 2003.

17. Kleger, Heinz, Ireneusz Pawel Karolewski, and Matthias Munkel. Europäische Verfassung: Zum Stand der europäischen Demokratie im Zuge der Osterweiterung [European Constitution: on the Current Status of European Democracy in the Context of the Eastern Enlargement]. $3^{\text {rd }}$ ed. Münster: Lit Verlag, 2004.

18. Llompart, José. "Proklamation der Volkssouveränität in den modernen Verfassungen [Proclamation of People's Sovereignty in the Modern Constitutions]." In: Werner Krawietz, Ernesto Garzón Valdés, and Agustín Squella, eds. Politische Herrschaftsstrukturen und Neuer Konstitutionalismus - 
Iberoamerika und Europa in theorievergleichender Perspektive, Rechtstheorie, Behiehft 13 [Political Structures of Governance and New Constitutionalism Iberoamerica and Europe in Theory-Comparing Perspective, Legal Theory, Supplement 13]. $1^{\text {st }}$ ed. Berlin: Duncker \& Humblot, 2000: 143 et seq.

19. Osmańczyk, Edmund Jan, and Anthony Mango. Encyclopedia of the United Nations and International Agreements. Volume 2: G-M. $3^{\text {rd }}$ ed. London: Taylor \& Francis, 2003.

20. Shaw, Malcom. International Law. $4^{\text {th }}$ ed. Cambridge: Cambridge University Press, 1997.

21. Vitoria, Francisco de. "De indis." In: Ulrich Horst, Heinz-Gerhard Justenhoven, and Jocahim Stüben. Francisco de Vitoria - Vorlesungen II (Relectiones) Völkerrecht - Politik - Kirche [Francisco de Vitoria - Lectures II (Relectiones) - Public International Law - Politics - Church]. $1^{\text {st }}$ ed. Stuttgart: Verlag W. Kohlhammer, 1997: 370 et seq.

\section{LEGAL REFERENCES}

1. United States v. Italy - Elettronica Sicula S.p.A. (ELSI). International Court of Justice, Judgment of 20 July 1989. ICJ Reports 1989: 15 et seq., 42 et seq.

2. German Federal Supreme Court. BGHZ Vol. 155: 279 et seq., 291 et seq.

3. Norms on the Responsibilities of Transnational Corporations and Other Business Enterprises with Regard to Human Rights. U.N. Doc. E/CN.4/Sub.2/2003/12/Rev.2 (2003). 